\title{
The Multiple Resistance Strategies for Survival under Israeli Occupation in the Novels of Sahar Khalifeh
}

\author{
Priyanka and Shashikantha Koudur \\ National Institute of Technology Karnataka, India
}

\section{Introduction}

The Palestinian territories have been occupied by Israeli military forces after the two great wars of 1948 and 1967. The war of 1948 between Israel and Arab countries is remembered as al-Nakba-catastrophe, which led to the rise of Israel as a nationstate that occupied the Palestinian territories. The war of 1967 is known as Naksa which means setback. In this, Israel emerged victorious and started occupying the territories like Gaza Strip and Sinai Peninsula from Egypt; the West Bank and East Jerusalem from Jordan and the Golan Heights from Syria. Currently, these places are under the Israeli military occupation. Consequently, it became inevitable for the Palestinians to protest against Israel's takeover of Palestinian territories through illegal occupation. Apart from this, Palestinians have been resisting Israeli colonial policies, expansion of settlements and illegal construction of the apartheid wall. Palestinians fight against the social injustice and degradation, inequality, economic exploitation, concentration of power and colonial oppression. Khalifeh's corpus of writing makes references to the Palestinian resistance that started from the period of British colonialism to the ongoing Israeli Occupation. This paper focuses on the Palestinian resistance movements to Israeli occupation. The important theories of resistance are proposed by James C. Scott (1989), Michel Foucault (1979), Frantz Fanon (1961) and Edward Said (1981). In 1985 James C. Scott introduced and developed the theoretical framework for "everyday resistance". On the other hand, Foucault discussed the unavoidable confrontation between resistance and power. Edward Said's writings focus on the representation and marginalization of genuine Palestinian resistance in Western discourse and media. On the other hand, the theories of resistance put forth by the anti-colonial critic Frantz Fanon, argue for the necessity of the armed resistance to fight against colonialism. Indeed, majority of the theories of resistance rely on the common presumption that the goal of resistance is to change the status quo. Resistance is not passive thinking; it believes in active participation in the movement until the goal is reached. Further, the outcome of resistance does not result in immediate change; the process is slow. 
Sahar Khalifeh's novels deal with the major political issues like exile, resistance, harassment and violence that form the core of the contemporary Palestinian predicament. This paper underlines the theme of resistance after the Palestinian Intifada (Uprising) as portrayed in the two novels of Khalifeh. Her novel AlMirath written in 1997 has been translated as The Inheritance by Aida Bamia. Another novel Rabi'harr written in 2008 has been translated as The End of Spring by Paula Haydar. These two texts highlight extensively on the multiple resistance strategies carried out by Palestinians during the time of uprising in their fight against Israeli occupation.

\section{The Inevitability of Resistance in the Context of Palestine}

Domination, oppression and suppression of a particular community under colonial rule give birth to resistance. Palestinian resistance movement changed its course systematically since the successive colonial dominations and political crises from Ottoman rule to the Israeli occupation. Qumsiyeh, in his work Popular Resistance in Palestine, traces a brief history of the emergence and development of Palestinian resistance movement since the Ottoman rule till the present day. Consequently, the popular resistance gained momentum in the occupied territories after the outbreak of the first Intifada in 1987. Qumsiyeh says that popular resistance in Palestine emerged and also "developed indigenously, organically, naturally and beautifully" (Qumsiyeh, 2011:p.1). "Muqawamasha'biya, the term commonly used in Palestine, is roughly translated as Popular Resistance. The word Sha 'biya has its roots in Sha'b (people) and is understood by many Palestinians as the kinds of resistance practiced by large numbers of the population, as opposed to more narrow armed resistance (muqawamamusallaha)" (ibid:p.11). The Intifada gave new dimension to Palestinian resistance movement where all Palestinian men, women, children and old people participated actively by throwing stones at Israeli soldiers. It became an obligation and commitment for everyone to fight against the ongoing Israeli occupation in a novel way. Popular resistance is carried out by the common people, and not by a single charismatic leader. It opens multiple avenues for contemplating new directions and new possibilities for the fight against the colonial oppression in the nationalist movement.

Resistance emerges as a struggle against entrenched power play. It seeks to challenge not only the existing power structure but also its socio-economic and political bases. There is a dialectical relationship between domination and resistance. Both are interdependent and the futility of resistance to gain power is the moot point. But the idea of resistance is intimately engaged in challenging different forms of hegemonic 
power structures and strategies. In this matter, Michel Foucault's writing consistently employs the term 'resistance' juxtaposed the term 'power'. He observes the inseparable relationship between the presence of power and resistance. Furthermore, he argues, both power and resistance have the same capacity to bring social change. One of the most well-known quotes of Foucault is, '[w] herever there is power, there is resistance, and yet, or rather by the same token, the latter is never external to power ... the strictly relational character of power's connections ... can only exist as a result of a multiplicity of points of resistance ... These points of resistance are present everywhere in the network of power' (Foucault, 1981:pp.125126). In the same vein, Lila Abu-Lughod observes that 'where there is resistance, there is power' (Abu-Lughod, 1990:p.42). According to Scott, the "... 'real resistance' is organized, principled, and has revolutionary implications" (Scott, 1989:p.51). These thinkers consider power as a distinct and central idea which affects the intensity of the resistance. Consequently, the level of subjugation or oppression with the use of power decides the quantum of resistance. Hence, different modes of resistance to power are natural and inevitable that challenges the hegemonic or counter-hegemonic power-relations. "As soon as there is a power relation, there is the possibility of resistance" (Foucault, 1989:p.153). So, the struggle is being conditioned constantly by the structures of social and political power. Resistance challenges the prevailing power imbalance consciously which leads to inequality and injustice. Indeed, Israeli Occupation has granted Israeli Jews the power to rule over the Palestinians of the occupied territories who have become powerless. Israel wields rigorous administrative control over the people. Further, the Israeli military regime is in control of currency, import-export trade, labor mobility and of all productive resources including land and water. Indeed, Palestinian resistance movement is manifested as everyday resistance, cultural resistance and popular resistance taking both violent and non-violent forms. It has been driven by a number of factors and motives.

\section{Resistance Literature}

Palestinian literature is an integral part of modern Arabic literature. The prominent Palestinian writer Ghassan Kanafani in his writings in 1966 about Palestinian literature, specially wrote about resistance (muqawamah) and emphasized its significance in portraying the living conditions of the Palestinians under Israeli occupation. Kanafani's term "Occupied Palestine" indicates the establishment of Israeli regime on the Palestinian land in 1948. His work acknowledges the uniqueness of Palestinian literature under Israeli rule which he termed as Resistance Literature. On the other hand, Kanafani described Palestinian literature as "an arena 
of struggle" (Harlow, 1987:p.2). In the formative years from 1948 to 1967 the literature of Palestine emerged as resistance literature a feature that is dominant till day. After 1948, Palestinian writing has appeared frequently as the precursor of resistance literature. Palestinian literature that appeared in the regions of West Bank and Gaza is known as literature from the occupied territories after 1967. The literature that came out from the occupied territories covers multiple issues like the brutality of the Israeli regime against the Palestinian community manifested in such forms as confiscation of Palestinian lands, demolition of houses, interrogation and humiliation at Israeli check points. Further, the effects of life of exile within the occupied territory and outside are very stressful. On the other hand, literature of all genres tends to portray the theme of resistance to Israeli occupation. Palestinian writers are continuously engaged with the pervasive political issues. One can say that the prime concern of the current Palestinian literature is to present the realities of the day-to-day life of Palestinian people to the rest of the world and thereby, to make the international community acknowledges their strife. Palestinian Intifada is a watershed movement and Palestinian literature about this movement has brought phenomenal changes in Israel, in Diasporas and in the occupied territories. During this period of Palestinian occupation, political prisoners from West Bank and Gaza produced the literature in jails and detention camps. The motif of the stone appeared as a major symbol in the Intifada literature. Apart from this, it has given birth to a new form of cultural resistance Graffiti. Fischer and Abedi refer to Graffiti as a 'minor media' (Fischer and Abedi, 1990:337). It is a cultural form of resistance which started in the late 1980s and early 1990s to communicate the political message to the various audiences. It covered the issues of gender, religion and politics. Most importantly it emphasized on the abnormality of everyday life under Israeli occupation and the mass resistance of Palestinians. These graffiti writings are humorous, threatening, and resistant to the dominant Israeli rule. In spite of the censorship, banning of books, jailing, torture, and assassinations, the Palestinian resistance succeeded in continuing the literary productions. Salma Khadra Jayyusi in her Anthology of Modern Palestinian literature says '[i]f Palestinians do not announce their experience to the world, surely the world is ready to forget them' (Jayyusi, 1992:p.69). Indeed, endeavors such as creating literature in Arabic as well as in other languages, translating literature into many languages, conducting Palestinian literary festivals, publication of newspapers, magazines, and journals, etc. became the prime concern of resistance literature. Acceptance and social transformation of the Palestinians are the offshoots of the genuine endeavors of Palestinian resistance literature. Consequently, it aims at bringing changes in their lives and livelihood. 


\section{Palestinian Women's Resistance to Israeli Occupation}

The condition that prevailed after the establishment of Israel, as an outcome of the 1948 and 1967 wars posed new challenges to the Palestinian women in their fight against Israeli colonial domination. Palestinian women got formal recognition to participate in resistance activities after the founding of the Palestine Liberation Organization (PLO) which is the sole legitimate representative of the Palestinian people in the early sixties. In the year 1964, women's participation in the PLO's first conference made a powerful resolution and women expressed their willingness to struggle along with men to liberate Palestine (Cooke, 1996:pp.171-172).

Usually, the role played by the women during the national crisis has been relegated to secondary importance in historical documents and literature without the exception of Palestine. Cooke in her book Women and the War Story highlights Widad Barghuthi's study on the representation of women's political role in men's poetry of the twentieth century. Barghuthi expresses her views about women's absence in the political scenario picturized in the writings of men. Specifically, she finds out that in poetry of male writers of the twentieth century, there is a zilch representation of the socio-political status of women. For instance, even though Arab women actively participated in the Arab revolt of 1930s, a poet of importance as Ibrahim Tuqan did not have any references to it in his poetry; instead he called them 'muses'. The same legacy continues even after the participation of women in resistance activities in the wars of 1948 and 1967. There is no significant change in patriarchal attitudes in accepting and presenting women's political role. Barghuthi mentions that even the participation of women in the Intifada did not bring any change in accepting women's representation in men's poetry (ibid:p.177).

Khalifeh's writings criticize the marginalization of the contribution of Palestinian women to national struggle in the narratives of men. Male writers completely ignored women's activities and their political and social agency; they were reduced to symbols and passivity. Khalifeh's writings express her disappointment with the symbolic representation of Palestinian women as land-like trope and ignoring the real experience and voice of the women in Palestinian resistance movement. Khalifeh challenges the dominant male discourses and explores the multiple roles played by the Palestinian women throughout the different historical periods of nationalistic struggle.

In his classical essay Everyday Forms of Resistance, James C. Scott defines everyday techniques of resistance as "small scale" and "relatively safe". It "promise[s] vital material gains' and 'require[s] little or no formal coordination'. However, this form of resistance needs "some level of cooperation" and to move forward as "a pattern 
of resistance" it relies "on a venerable popular culture of resistance" (Scott, 1989:pp.35-36). Scott's depiction of every day acts of resistance has lot of similarities with the concept of al-sumud in Arabic, translated as steadfastness. Steadfastness means to maintain normality in everyday life, even under the extraordinary political upheavals. Like everyday resistance, steadfastness underlines the different modes of survival techniques. It includes staying in motherland, displaying humanitarian behaviour, adhering to normal living style in the adverse circumstances of oppression by the colonizers or under the imposed systems. Michel de Certeau claims that everyday resistance is about the "way of using imposed systems" (de Certeau, 1984:p.18, emphasis in original). He says people use "popular tactics" for their survival (ibid). Steadfastness has been embedded in their attitudes and lifestyles.

Khalifeh introduces the female character, Madame Mayor in the novel The End of Spring, which is the best illustration of a character leading the life of everyday resistance. Her husband has been imprisoned for twenty years in Israeli prison for his involvement in resistance activities. In his absence she looks after her children. In order to procure the basic amenities to the family she sells her golden bracelet and brings a weaving loom. Gradually, she multiplies the weaving looms and generates employment opportunities for other women as well. Madame Mayor engages in mobilizing and empowering women in order to support their families in the absence of the traditional breadwinners.

In the novel Khalifeh depicts the repeated invasions and bomb shelling by the Israeli forces using sophisticated weapons. The Jews attack the city of Nablus belligerently by dropping bombs and by shooting rockets. The Jewish assaults are unexpected; people of Nablus become panicky, women and children start creaming. Jews announce over the loudspeakers, '[p]eople of Nablus, you whores, we're coming to screw you' (Khalifeh, 2008:p.184). In this critical and terrifying situation, Mayor and the team of women engage themselves with the community kitchen, Hosh alAtout. She perceives it as her duty to serve food for poor civilians, fighters and security officers. For her, the violent attacks of Jews have become a routine matter and she supports the civilians to cope with the terrible situation. Ahmad is the younger son of Fadel al-Qassam, a courageous reporter who comes from the town of Ayn al-Mirjan. Ahmad being a young boy gets attracted towards beautiful Jewish girl - Mira the daughter of an Israeli settler who is from the other side of the fence separating his town of Ayn al-Mirjan. In spite of his father's warning, Ahmad starts visiting her along with his adored kitten - Ambar. Their friendship ends abruptly when Mira steals his kitten. When Ahmad and his cousin Issa attempt to rescue the kitten, both are caught and tortured terribly inside the Israeli prison. After the release from the prison, Ahmad's behavior changes drastically, he loses his innocence and 
sensitivity. He isolates himself from home and takes shelter in Mayor's house. He discontinues his studies and starts to work for the Red Cross with the first aid in an emergency unit. Ahmad has seen the large number of casualties in the hospital due to the violent attack on the natives of Nablus. He takes break from his duty and comes to Mayor's place. He struggles to forget the site of sufferings of the civilians in the hospital. Understanding the psyche of Ahmad, Mayor offers him food, but he refuses to have it. She consoles him, '[y]ou should eat, because you're young. You have your whole life ahead of you. Eat so you can grow and become an adult' (Khalifeh, 2008:p.189). All of Mayor's children have migrated to different places except Suad who follows the footsteps of her mother and engages with resistance activism.

Sitt Amira is an educated woman in The Inheritance, who speaks French and English fluently. Amira supports the fighters giving sweaters knitted by her and providing medical care. Apart from this she listens to Haykal's articles read at Sawt al-Arab radio station in the 1960's. She frequently attends the diwan gatherings and believes that these meetings make her aware of the larger socio-political scenario. She names her son Abd al-Nasser, after Nasser, a prominent Arab nationalist indicating a strong belief in Arab nationalism. Throughout the novel, Khalifeh portrays the character Sitt Amira as an active, independent and courageous woman.

In the same novel Nahleh, a single woman, who works as a teacher in Kuwait, supports the movement by donating a golden bracelet. She laments for the injured revolutionaries and orphans. She is worried about the failure of the revolution. She perceives that her donation is meager as compared to the fighters who are ready to give up their lives for the cause of the movement. Edward Said in his work Culture and Imperialism insists that the Palestinian men and women must work hand in hand to bring the change. "These changes cannot occur without the willingness of men and women to resist the pressure of colonial rule, to take up arms, to project ideas of liberation, and to imagine ... a new national community, to take the final plunge" (Said, 1994:p.241). Steadfastness is one of the forms of resistance used by the Palestinians to challenge the Israeli Occupation. It comprises of coping with the terrible situations, adopting survival techniques and compliance of living under Israeli Occupation.

\section{Cultural Resistance}

The cultural resistance through music, dance, fine arts, literature and folklore helps Palestinians in the fight against Israeli Occupation. The very act of producing art and the participation in the cultural activities under Israeli military occupation act as resistance. The cultural forms of resistance have a more precise catalytic effect: it 
encourages not only the elite group to participate but also gives voice to the subalterns. The cultural resistance voices out political messages which criticize the assumptions of the cultural supremacy on part of the colonizers. Moreover, they strive to preserve their native identities and cultural uniqueness to fight against the culture of the colonizers. The visual arts like paintings, sculptures, cartoons, installations, films, photography and videos also play a key role. The production of other cultural artifacts such as poster, graffiti, song, play, etc. also becomes part of the spectacle of cultural resistance. Khalifeh, in The Inheritance, portrays Nahleh's brother Mazen as a revolutionary, a victim of a mine explosion that occurred during an activity of resistance. He thinks that the Israelis can be defeated with cultural resources the Palestinians possess. He conducts a cultural fair and believes that cultural resistance in such form is the best way to fight against the Israeli Occupation. Mazen tells his cousin Zaynab '[t]hey defeated us through the war but we will defeat them with our culture. This is a cultural struggle' (Khalifeh, 2005:p.103).The various forms of art can be explicitly linked to a political resistance movement and it makes the artistic attempt to challenge the political hegemony. The Palestinian universities have been conducting seminars, symposia, conferences, literary festivals, and public lectures on literature, Palestinian folklore and its political milieu. Apart from this, wearing traditional national costumes, singing Palestinian national anthem, having traditional food and using home made products have become part of cultural resistance.

David A. McDonald in his book My Voice is My Weapon: Music, Nationalism, and the Poetics of Palestinian Resistance, argues that music plays a predominant role in Palestinian resistance movement with the motive to topple Israeli occupation. He focuses on the role of music and performance by Palestinians which help build a positive national identity and help understand the cultural resistance and its value in the occupied territories as well as in the diaspora. Eventually, Palestinian performers have invoked nationalistic feelings by blending traditional music with modern music. On the other hand, Palestinian performers have been learning new forms of music such as hip-hop to reach out to the global audience. McDonald showcases various musical forms which act as resistance in a very dynamic and divergent way (McDonald, 2013).

In the novel The End of Spring, Majid is the eldest son of Fadel al-Qassam. He is an artist who inherited the singing talent from his mother. He is a multitalented person - an amazing singer, a guitar player and famous for his dabke (Arab folk dance) steps. His band performs in parties and concerts; he sings patriotic songs in the pop culture style of the west. Majid is popular among his fellow students, yet, he lacks the experience of participation in the resistance. He knew revolution only through the lyrics that he sang at the concerts. As the novel progresses, he transforms himself 
from an artist to a resistant fighter. Fadel al-Qassam rather approves of Majid's activities in comparison to that of his younger son Ahmad who is a day dreamer and an over-sensitive person. He is an artist as well, who paints beautiful landscape. His father is disappointed because his son fails to represent the harsh realities of the occupation. Yet, his father encourages him by gifting him a camera and advices Majid to take him around the town to understand the realities of life.

\section{Martyrdom Operations}

Suicide bombings have become the important components of the Palestinian resistance movement. The second Palestinian Intifada that erupted in September 2000 had marked intense use of violence as a strategy for resistance. In the Palestinian context, the suicide bombings have been supported politically, culturally, and religiously as a powerful mode of resistance. Nasser Abufarha in The Making of a Human Bomb: An Ethnography of Palestinian Resistance, details out the several factors leading to the increased incidents of suicide bombings in the occupied territories of Palestine. The incidents of suicide bombings did not occur immediately after the Israeli Occupation. After witnessing twenty-nine years of colonial rule, the first Palestinian suicide bombing took place in 1994 after the failure of Oslo peace process of the 1990s (Abufarha, 2009:p.7).

The martyrdom operations have gripped the attention not only of the Israelis but also of the international community. It has been carried out in Palestine by Palestinian outfits against Israeli targets. 'Suicide bombings' being a western reference to the act, the Palestinians call it as amaliyyatistishhadiya (martyrdom operation), bringing in a sense of eulogization. The martyrdom operations have been interpreted differently by other nations and they strongly criticize it as a heinous crime. The victims of colonization consider martyrdom operations as a visible and effective means to send imperative message to the colonizer. These martyrdom operations have also been referred as "homicide bombing" by George W. Bush as well as British government officials, a term originated in the wake of the global war on terror. Nevertheless, in the western media, these martyrdom operations by Palestinians are not addressed as self-sacrificing operation. Even though self-sacrifice is evident, the core of the act of the operations has been sidelined by the media. Israeli occupation has affected the younger generation intensely, who have been growing up in terrible conditions. They are adopting new and alternative strategies of resistance to challenge the atrocities committed by the occupiers. In The End of Spring, Khalifeh indicates an increasing number of young suicide bombers. The older generation expresses apprehension about their children who are fighters, agents, and 
collaborators of the resistance activities even as the children who have been witnessing the atrocities of Israeli Occupation prepare themselves for physical forms of resistance. Khalifeh writes, ' $[\mathrm{t}] \mathrm{hey}$ were without hope, and so they sacrificed themselves, made themselves into bombs that walked around on two feet ...' (Khalifeh, 2008:p.116). Foucault eloquently captures the affiliation between body and politics when he writes, '[t]he body is directly involved in a political field; power relations have an immediate hold upon it; they invent it, make it, train it, torture it, force it to carry out tasks, to perform ceremonies, to emit signs' (Foucault, 1979:p.25).

\section{The Ideology of Self-Sacrifice in Martyrdom Operations}

Moreover, the act of martyrdom is acutely based on the performative act of the body. The perpetrators of martyrdom operations are bound by the strong ideology that their body is a symbol of devotion and submission to a nationalistic cause. Such a person who sacrifices his or her life is considered a hero or a freedom fighter in the community and is eulogized. Martyrs' bodies have become emblematic of the Palestinian struggle for nationhood. The strategy and ideology of martyrdom differs from one group to another and the intention of undertaking the extreme act varies from one individual to another. Martyrdom operations have become the choice of an individual or a group who are willing to sacrifice for the nation. Martyrdom operations, ironically, have become an act of self-defence for oneself and one's community.

Achille Mbembe in his essay Necropolitics, seeks to establish a linkage between the apparently incompatible dimensions of logics such as "the logic of martyrdom and the logic of survival" by emphasizing the dual issues of "death and terror" and also "terror and freedom" in the context of Palestine (Mbembe, 2003:p.35, emphasis in original). According to him, terror and death are inseparable entities. They are the two sides of the same coin. The paradigm for survival under colonial rule gives scope for self-sacrifice as well as the murder of the enemy. The main intention of killing an enemy is to live and sometimes they kill themselves to live. Life and death are inextricably linked to freedom struggle and it is also a question of survival. Khalifeh writes, ' $[\mathrm{k}] \mathrm{ill}$ in order to live, die in order to live. In other words, life and death cannot be separated when we thought about freedom' (Khalifeh, 2008:p.84). The discourse of sacrifice and martyrdom challenges the usual privileging of life over death. It gives new connotation to death that is about living, not dying.

Self-sacrifice is necessary for the survival. In the novel The End of Spring, Khalifeh narrates the intensified seize of former President Arafat's quarters in Ramallah by 
the Israeli army during the second Intifada. The Israeli army, before starting shelling, had cut off all the networks like airlines, antennas, cell phones in order to restrict the communication with the outer world. The authorities inside Arafat's quarters were not able to access water and electricity. They attacked with bombs and missiles which came from every possible direction. One of the guards of Arafat who knew he would be dying in this attack, writes on the wall in large and bold letters 'welcome sweet fragrances of heaven' (Khalifeh, 2008:p.169). Majid enters the president's quarters and views the reactions of Arafat on the unexpected sudden seize. Arafat says to his supporters, 'welcome to death for the sake of life' (ibid:p.167). His followers shout the slogans, "with our souls, with our blood, we sacrifice for Palestine!' (ibid:p.168).

Martyrdom operations have been the most painful and the most conspicuous form of resistance. Merciless killings of Palestinian civilians and assassination of the activists or leaders forced Palestinian youths to opt for the martyrdom operations. The novel The End of Spring, reaches the climax with the people carrying out antidemolition demonstrations opposing the construction of the wall. The peasant woman pounds her chest and cries for the olive trees that are being uprooted. An Israeli soldier pushes a woman out of her way in front of bulldozers in order to destroy houses and trees. Ahmad's father stands in front of the bulldozer in order to stop the demolition of the house. The international activist, Rachel, tries to protect Ahmad's father, but she dies in the effort, being crushed by bulldozer. Ahmad's anger surmounts, and he recalls the earlier atrocities committed by Israeli army. Ahmed loses control and recalls and carries out his revenge on occupiers:

"Go. Go!" the young men shout. "Step on it! Go!” Ahmad steps on the gas pedal, muttering like a lunatic, "Sons of bitches!" Anger overpowers fear and the world becomes a blur through his tears ... He surges forward with all his might, like a rocket, toward the soldiers. Five, seven, ten, or more. $\mathrm{He}$ can't tell. His mind has gone blank. He sways. His soul flies up like a kite, like ozone" (Khalifeh, 2008:p.276).

His father grieves for his death and accepts that he "has been martyred!" (ibid:p.276). The following day Ahmad's death was represented as "Terrorism" in the news (ibid). Eventually, after the 9/11 incident of 'War on Terror', terrorism has been most frequently ascribed to the Arab nations and to Islam. More precisely, the Palestinian resistance has been often branded as terrorism or insurgency. The tenor of these clichés challenges the legitimacy of the Palestinian institutions. Stereotypes on these lines are produced, circulated and reproduced in the Western world through literature, official discourses and mainstream media. This is also expressed through visual media like photos, films, and web pages. Edward Said in his work Covering 
Islam says that it is a common tendency to reduce Islam to a handful of rules, stereotypes, and generalizations about the faith, its founder, and its entire population. Islam is projected as violent, primitive, and fundamentalist (Said, 1981:p.xvi). Khalifeh writes ' $[t]$ he west sees us in a very ugly and negative light. One-minute Saddam, the next Arafat, and the next some Bedouin with a dirty lice-infested beard holding a knife behind his back' (Khalifeh, 2008:p.65). Eric Walberg, a well-known journalist, in his book Islamic Resistance to Imperialism argues that the word "terrorism" is deceptive, which does not have legal definition in the West. It is considered always a synonym for "Islamism" or "jihadism". It is used spontaneously 'by officials and the media to delegitimize the state's political opponents' (Walberg, 2015:p.27).

\section{Limitations of Palestinian Resistance}

Khalifeh in her novels exposes how Palestinian revolution witnessed failure most of the times. According to her, the reasons for the failure of the nationalist movement are the lack of support within the Palestinian community and the inability to understand the nationalist agenda. She specifies the misuse of political power by the great Palestinian leaders and the authorities. Indeed, Khalifeh in her writings criticizes not only the violence of Israeli and American imperialism but also of her own Palestinian society. She exposes the changing political scenario under the leadership of Yasser Arafat who indulged in corrupt activities. Cooke in her essay "Talking Democracy" says about Khalifeh '[w]riting from within the Occupied Territories, she is expected to represent her nation uncritically. Self-criticism is out' (Cooke, 1996:p.197). This is a misconception about the writings of Khalifeh. As an insider of the occupied territories, her depictions of the realities and flaws of the resistance movement are courageous. Khalifeh, in one of her interviews defines genuine nationalism as 'to know and to love the nation with its rights and its wrongs, its sweet and its bitter, because without diagnosis there can be no prescription' (Quoted in Cooke, 1996:p.170). Khalifeh's novels provide much fodder for discussion on the failure of Palestinian resistance. Unfortunately, Palestinian national cause has neither been getting valuable support from Arab nations nor much of the International community. This is one of the main reasons for the status-quo of the Palestinian problem. The collective exile of Palestinian community that has scattered around the globe is also a reason for the failure of the resistance movement. It is difficult to organize and mobilize resistance activities effectively against Israeli Occupation, when the community is dispersed all over the globe. 
The Palestinians who live in the occupied territories - the "insiders" blame the "outsiders" for the lack of support to carry out their resistance mission. The binary ideological difference between Mazen (insider) and Kamal (outsider) in the Palestinian resistance has been expressed in The Inheritance. Mazen views Palestinian rebellion in a very optimistic way. On the other hand, Kamal judges Palestinian insurgency in a pessimistic framework. Mazen exclaims to Kamal that though Palestine has been defeated twice, they are hopeful with their dream of vanquished Israeli Occupation. Mazen appreciates that Palestinians are energetic enough to overcome the two defeats and achieve nationhood. He emphasizes that in order to build a nation they should not stop their political commitment and endless conversations. Mazen proudly says, '[1]ife is work and commitment' (Khalifeh, 2005:p.189). On the contrary, Kamal disagrees with Mazen who stresses onthe commitment towards political and personal lives. He attacks Mazen for the failure, for having lack of commitment neither to the family nor to the revolution, since the revolution too, seems to be a never ending one. He despondently says, '[1]ife is commitment and it's work; the revolution gave us nothing but theories and poetry!' (ibid:p.189).

The Palestinian resistance activism fails occasionally because of lack of support from the family members. In The Inheritance, Mazen's father expresses his anxiety to Zayna that all his sons are educated and settled, but for his son Mazen who is engaged enthusiastically in resistance activities. He blames his son who lives in the idealistic image of Guevara (the Latin-American revolutionary) which is not realistic. His father says, '[h]e has to wake up and look to his own interests. Who is he counting on? He has to wake up and take care of himself. Whatever he does he is still Mazen Hamdan, not Guevara. Tell him that' (ibid:p.71). Mazen's sister Nahleh expresses her disappointment about her brother who left the university in order to become a revolutionary. According to her sister, he is an unemployed, pseudo intellectual and freedom fighter who worries about the grievances of the whole world. She complains that he wastes his time talking about revolution all the time.

Khalifeh's novels consciously and deliberately deal with the weaknesses in Palestinian resistance strategies. Mazen's beloved Violet in the novel gives an account of how male revolutionaries misuse power. She says male revolutionaries are overwhelmed with their emotions, they speak about the revolution and are addicted 'to hashish or morphine' (ibid:p.179). Further, she articulates the sexual exploitation of women by the revolutionary leaders. She talks about how girls are seduced and then abandoned. She compares their situation to that of prostitutes, who are at least paid for their service. She says, '[t]hey were seduced the same night by a poet, a leader, or even an intruder to the revolution, and a would-be poet' (ibid). These girls happen to be the misfortune of the revolution and of the liberation 
movement. Here, Khalifeh is making an evident gesture that instead of focusing on women's empowerment; Palestinian resistance movement ends up with the sexual exploitation of women. Poets, leaders and would-be poets, who are the "legitimate" revolutionaries of the movement, freely exploit women, who are nobody for them and who are also the participants in the very same movement. Both her novels echo the huge limitations of Palestinian revolution.

\section{Implications of the Multiple Resistance Strategies}

Israel established a repressive system of control using certain logics on the Palestinians in the occupied territories to curb the spirit of Palestinian resistance movement. More specifically, Israel's war against the Palestinians is waged at three levels. The first level involves the process what Orlando Patterson calls "social death" (Moughrabi, 1992:p.48). This is an effort to eliminate their sense of identity as a nation. They purposefully try to eliminate their national sentiments by attacking on their national symbols like flag, national anthem and songs or folklore. Secondly, Israel uses what Austin Turk calls "political policing" (ibid:p.49) in order to control the behaviour of the Palestinians. They use the tactics of divide and rule policy which almost results in political death. Consequently, this situation forces them to give up the notion of independent nationhood. Thirdly, they curb the economic activities of the Palestinians. In this level, they try to control the infrastructure of the occupied territories very logically by confiscating their lands and controlling water resources and thus making the Palestinians depend upon Israel for survival. Lastly, utilizing these logics, Israeli authorities deprive the Palestinians of their basic amenities.

Palestinian resistance movement in the occupied territories of West Bank and Gaza Strip has been systematically controlled by Israel through excessive use of force. Furthermore, these settlers employ the use of excessive physical force in order to create violence and bloodshed raging war against the Palestinians. The Israeli authorities use massive forces designed specifically to create an environment of fear and coercion. It controls the national uprising through extreme violence through demolishing the houses or threatening through demolition acts, damaging the education system, confiscating the lands, restricting movement, imposing fines, taking away work permits, ransacking the homes and civil institutions, conducting raids on the houses in the night, confiscating the properties, kidnapping ,injuring, and killing the people. Moreover, there is a colour coded permit system, and arbitrary imprisonment. Palestinians were punished severely after the first Intifada by Israelis in order to deter them from their activism. 
"As of the second quarter of 1991, 962 Palestinians were killed by the Israeli authorities, of whom 252 were 16 years old or younger. Many of the youth shot to death were killed by bullet wounds to the upper torso or the head, leading to speculation that the Israeli authorities may have been positioning snipers with their patrols. An estimated 115,118 people have sustained injuries. Sixty-six activists have been deported while some 15,100 out of a total population of 1.7 million are held in administrative detention without charge or trial. Excluding the period of the Gulf War, when the entire area was placed under curfew throughout the duration, the Israeli authorities imposed 10,212 days of curfew on various parts of the territories. Over 100,000 trees have been uprooted and 375,753 dunums (a dunum is roughly .25 acres) of land have been confiscated. A total of 1,971 houses have been sealed or demolished by the occupation forces" (Moughrabi, 1992:p.46).

Palestinian mothers are facing a major challenge of deterring their children who are eager to participate in resistance activities. Many Palestinian children are the victims of harassment through beating, abuse, kidnapping, and killings by Israeli soldiers. The extreme violence from both the sides has created fear, anxiety and insecurity among the young minds. The children have been deprived of their fun of playing in the streets, going to the schools without fear and enjoying their childhood. On the other hand, Palestinian mothers have been accused that they encourage their children to engage in resistance activities. As a result of military or political oppression, there is an increase in the killings of their young children. These deaths by killings are glorified as "holy", "noble" and "worthy" and Palestinian mothers are acknowledged as mothers of martyrdom. In reality, '[d]epression, anxiety, psychosomatic symptoms, and symptoms of Post-Traumatic Stress Disorder not only were found to be common amongst Palestinian women but were also more intense than those experienced by their male counterparts' ( Shalhoub-Kevorkian, 2003:p.391).

Israelis' extreme use of violence to control the multiple resistance strategies are not criticized uniformly worldwide. Instead, Israel has been projected as a nation in search of peace. Israel is projected as the only democratic country in the Middle East. In her recent article, a contemporary Arab-American writer Susan Abulhawa "The Searing Hypocrisy of the West" states, '[w]hen we take up arms and fight back, kidnap a soldier, we are terrorists of the extreme kind who have no one to blame but ourselves as Israel subjects the entire Palestinian population to punitive collective punishment. When we engage in peaceful protests, we are rioters who deserve the live fire they send our way. When we debate, write and boycott, we are anti-Semites who should be silenced, deported, marginalized or prosecuted' (Abulhawa, 2014:p.10). In spite of these challenges encountered by the Palestinians, the resistance movement has become a remarkable indication to show Israel that 
Palestinian struggle is still alive. In other words, despite these series of horrors, Palestinian resistance to the Israeli occupation goes unabated.

\section{Conclusion}

Khalifeh's writing does not represent Palestinian struggle with exaggerated and idealistic views. However, Khalifeh practically draws upon the challenges and weaknesses in resistance strategies while fighting against the colonial oppression. She says, "... it's a society rather than a symbol, a slogan, a song, or an allegorical beloved. We're people of blood and flesh and weaknesses, as well as strengths" (Jaber, 2009). The main aim of Palestinian resistance is to communicate their ongoing struggle through different ways of expressions to the rest of the world, in order to avoid the Western and Israeli misrepresentation of Palestinian resistance movement or limiting their struggle only to terror symbols. Khalifeh portrays the collective and group violence perpetrated by both Palestinians and Israelis in the wake of resistance movement. However, in the last decade there has been an alarming increase in the use of violence from both the sides. Zygmunt Bauman says '[i]t is a banal truth that violence breeds more violence; somewhat less banal, since not repeated enough, is the truth that victimization breeds more victimization. Victims are not guaranteed to be morally superior to their victimizers, and seldom emerge from the victimization morally ennobled' (Bauman, 1992:p.236). Khalifeh's novels mirror the various ways in which power has been exercised by colonizers and resisted by the natives. Palestinian resistance is inevitably taking new turns throughout the vicious period of colonial domination, from non-violence to violence, from community to individual orientation and from the Islamic to the secular or the religious to the non-religious. These multiple strategies articulate the acute urge among Palestinians to fight against Israeli occupation in order survive. Khalifeh describes the relationship between occupation and resistance thus: ' $[t]$ he occupation meant contradictions: revolution versus debasement, collaboration versus sacrifice, vileness and depravity and espionage versus the ultimate sacrifice, blowing oneself up' (Khalifeh, 2008:p.116).

\section{References}

Abufarha, N. The Making of a Human Bomb: An Ethnography of Palestinian Resistance. Durham: Duke University Press, 2009. Print.

Abulhawa, S. (2014) "The Searing Hypocrisy of the West." The Hindu, [online]. 
Abu-Lughod, L. (1990) The Romance of Resistance: Tracing transformations of Power through Beduin Women. American Ethnologist, Vol. 17 (1): 41-55.

Bauman, Z. (1992). Soil, Blood and Identity. The Sociological Review, 40(2): 675-701.

Cooke, M. (1966). Women and the War Story. Berkeley: University of California Press.

De Certeau, M. (1984). The Practice of Everyday Life. Berkeley: University of California Press.

Fanon, F. (1967). The Wretched of the Earth. Trans. Constance Ferrington. London: Penguin Book.

Fischer, M, and Abedi, M. (1990). Debating Muslims: Cultural Dialogues between Tradition and Postmodernity. Madison: University of Wisconsin Press.

Foucault, M. (1979). Discipline and Punish: The Birth of the Prison. New York: Vintage Books.

- - -, (1981).The History of Sexuality, Vol. I. Trans. Robert Hurley, Harmondsworth: Penguin.

- - -, (1989). The End of the Monarchy of Sex. New York: Semlotexte.

Harlow, B. (1987). Resistance Literature. New York: Methuen.

Jaber, E. (2009). "A Provocative Writer Who Challenges and Ridicules Authoritarians and Calls for Change, SaharKhalifeh: My Work is Realist, From People, Towards People." Trans Sami Hanna. Assafi rCultural Supplement, Friday March 27, 2009. Web. Original Arabic at<http://www.assafir.com/Windows/ArticlePrintFriendly. aspx?EditionID=7090\&WeeklyArcticleID=54733.>

Jayyusi, S. K. (1995) Anthology of Modern Palestinian Literature. New York: Columbia

Khalifeh, S. The End of Spring. (2008). Trans. Paula Haydar. Northampton, MA: Interlink Books.

- - -, (2005). The Inheritance. Trans. Aida Bamia. New York: The American University Cairo Press.

Mbembe, A. (2003). Necropolitics. Trans. Libby Meintjes. Public Culture. Duke University Press, 15(1):11-40.

McDonald, D.A. (2013). My Voice is My Weapon: Music, Nationalism, and the Poetics of Palestinian Resistance. Durham: Duke University Press.

Moughrabi, F. (1992). “Israeli Control and Palestinian Resistance”. Social Justice, 19:3(49), p. $46-62$.

Qumsiyeh, M.B. (2011). Popular Resistance in Palestine: A History of Hope and Empowerment. London: Pluto.

Said, E. (1981). Covering Islam. London: Vintage.

- - - , (1994). Culture and Imperialism. London: Vintage.

Scott, J. C. (1989). "Everyday Forms of Resistance". Copenhagen Papers, 4(89), p.33-62.

Shalhoub-Kevorkian, N. (2003). Liberating Voices: The Political Implications of Palestinian Mothers Narrating their Loss. Women Studies International Forum, 26(5), p. 391-407. University Press.

Walberg, E. (2015) Islamic Resistance to Imperialism. USA: Clarity Press, Inc. 


\title{
Summary
}

\section{The Multiple Resistance Strategies for Survival under Israeli Occupation in the Novels of Sahar Khalifeh}

\author{
Priyanka and Shashikantha Koudur \\ National Institute of Technology Karnataka, India
}

The Israeli-Palestinian conflict that started after 1948 war persists to play a dominant role in shaping Palestinian resistance movement. Sahar Khalifeh is a renowned Palestinian writer of the West Bank which is one of the Israeli occupied territories of Palestine. The core theme of Khalifeh's writings is the Palestinian resistance to Israeli Occupation. This article examines specifically the multiple resistance strategies adopted by both Palestinian men and women on a land which is under prolonged Israeli occupation. Indeed, the Palestinian resistance movement constitutes both violent and non-violent forms of resistance throughout their struggle for independence. Unfortunately, the media has sidelined the issue of civil or non-violent forms of resistance movements pursued by the Palestinians and represented the Palestinian resistance grossly as an act of terrorism or insurgency. This paper analyzes the different ways of resistance carried out by the Palestinians and the limitations thereof, as depicted in the two novels of Khalifeh-The End of Spring and the Inheritance.

Keywords: Resistance, Israeli Occupation, Power, Martyrdom, Self-Sacrifice 